\title{
Short communication: Characterization of early postpartum estrous behavior and ovulation in lactating dairy cows using radiotelemetry
}

\author{
C. R. Johnson, ${ }^{\star}$ M. W. Ayers, ${ }^{\star}$ A. Ahmadzadeh, ${ }^{\star}$ B. Shafii, † S. Etter,‡ R. C. Chebel,§ and J. C. Dalton ${ }^{\star 1}$ \\ ${ }^{*}$ Animal and Veterinary Science Department, and \\ †Statistical Programs, College of Agriculture and Life Sciences, University of Idaho, Moscow 83844 \\ fUniversity of Idaho Extension, Caldwell 83605 \\ §Veterinary Population Medicine Department, College of Veterinary Medicine, University of Minnesota, St. Paul 55108
}

\section{ABSTRACT}

The objective of this study was to describe early postpartum estrous behavior and ovulation in lactating dairy cows using radiotelemetry. Cows $(\mathrm{n}=50)$ were continuously monitored for behavioral estrus with a radiotelemetric system, HeatWatch II (CowChips LLC, Manalapan, NJ), from d 14 to approximately d 49 postpartum. Blood collection for analysis of progesterone and ovarian ultrasonography were performed once weekly starting on d 14. First ovulation was associated with behavioral estrus in 5 cows and occurred at 28.2 $\pm 10.8 \mathrm{~d}$ (mean $\pm \mathrm{SD}$; range 17 to $40 \mathrm{~d}$ ). The average duration of estrus was $6.0 \pm 4.9 \mathrm{~h}$ (range 3 to $12.2 \mathrm{~h}$ ), and the mean number of standing events was $18.4 \pm 8.9$ (range 4 to 26). Based on progesterone concentrations of $\geq 1 \mathrm{ng} / \mathrm{mL}$, estimated first postpartum ovulation occurred at $25.1 \pm 10.4 \mathrm{~d}$ (range 10 to $49 \mathrm{~d}$ ) for 38 animals without evidence of behavioral estrus. The interval to estimated first ovulation without behavioral estrus was not different from the interval to first ovulation associated with behavioral estrus. Level of milk production and body condition score loss did not affect the interval to estimated first ovulation without estrus or first ovulation associated with estrus. Six animals did not show evidence of ovulation based on progesterone concentration, whereas 1 cow showed evidence of estrous behavior on the day before removal from the study. The majority of first postpartum ovulations $(38 / 43 ; 88.4 \%)$ were not associated with behavioral estrus.

Key words: estrous behavior, radiotelemetry, postpartum

\section{Short Communication}

Early postpartum estrous behavior in modern dairy cattle has not been well defined. Shipka (2000) used

Received October 21, 2011.

Accepted May 8, 2012.

${ }^{1}$ Corresponding author: jdalton@uidaho.edu radiotelemetry (HeatWatch, originally developed by DDX Inc., Denver, CO), blood progesterone, and visual estrous detection to characterize silent ovulations in multiparous Holstein cows. From the progesterone and radiotelemetry data, almost $42 \%$ of all first postpartum ovulations were not accompanied by a standing event of estrus (Shipka, 2000).

The reproductive efficiency of lactating dairy cows has declined (Lucy, 2001; Washburn et al., 2002). Lucy (2001) reported that pregnancy per AI decreased from $55 \%$ in the 1950s (Casida, 1961) to $45.3 \%$ for cows that were artificially bred following spontaneous estrus (Dransfield et al., 1998). Following Ovsynch (without presynchronization) and timed AI, Pursley et al. (1997a,b, 1998) described a range of pregnancy per AI from 32 to $45 \%$. Presynchronization, coupled with improvements to Ovsynch, have resulted in pregnancy per AI of $45 \%$ following timed AI (Brusveen et al., 2008).

Presynchronization and timed AI facilitate first AI; however, regional differences exist in the United States regarding the adoption of these management strategies (Moeller et al., 2010). On dairies that do not incorporate presynchronization programs, reproductive management of cows between calving and the end of the voluntary waiting period may be minimal, including cursory estrous detection. Consequently, a lack of understanding about early postpartum estrous behavior and cyclicity status may hinder effective management intervention before the end of the voluntary waiting period. Therefore, the objective of this study was to describe, in a commercial dairy setting, early postpartum estrous behavior and ovulation in lactating dairy cows using radiotelemetry and progesterone analyses, while verifying the occurrence of ovulation with ovarian ultrasonography. In addition, we hypothesized that cows with higher milk production would have delayed days to first ovulation, and those cows with greater BCS loss during the study would have delayed days to first ovulation.

This study was approved by the University of Idaho Animal Care and Use Committee and was conducted 
from June 2007 to April 2008. Lactating Holstein (n $=49$ ) and crossbred (Brown Swiss $\times$ Holstein; $\mathrm{n}=$ 1) cows from a commercial dairy located in southern Idaho were used in this study. Cows were housed in a combination freestall-open lot facility, and were fed a TMR formulated to meet or exceed the nutritional requirements for lactating Holstein dairy cows (NRC, 2001). Cows were milked 3 times daily, and annual average milk yield was $12,310 \mathrm{~kg} / \mathrm{cow}(\mathrm{n}=1,315$ cows $)$. Cows were restrained in headlocks for $1.5 \mathrm{~h}$ daily to facilitate management. Upon release, animals had access to drylot and freestall facilities.

Healthy cows $(\mathrm{n}=31$ multiparous and $\mathrm{n}=19$ primiparous) with no previous history of dystocia or disease were continuously monitored for behavioral estrus by HeatWatch II (CowChips LLC, Manalapan, NJ) from d 14 to approximately d 49 postpartum. HeatWatch II is a radiotelemetric estrous detection system that includes a transmitter (contained in a patch that is glued to the hair caudal to the sacral region), a base station, access point, and supporting software. When activated for a minimum of $2 \mathrm{~s}$, the transmitter emits a radiowave that includes transmitter ID number, date, time, and duration of activation, as described previously in a study using the original HeatWatch (Dransfield et al., 1998). HeatWatch II differs from the original HeatWatch system as follows: (1) it uses a redesigned, contoured transmitter (in which activation may occur following pressure anywhere on the surface of the transmitter) with the capacity to store data; (2) the receiver and buffer of the original HeatWatch system were replaced by a base station and access point, respectively, which allows for 2-way, wireless communication between the transmitters and access point; (3) the base station receives and stores data, and using wireless technology, transmits data to the computer and HeatWatch II software via the access point; and (4) enhanced software provides several management lists.

Cows were determined to be in estrus when 3 or more standing events were recorded by the HeatWatch II software in any 4-h time period (Dransfield et al., 1998). Onset of estrus was identified as the first recorded standing event. Duration of estrus was defined as the interval in hours from the first standing event to the last standing event in an estrous period. Intensity of estrus was defined as the number of standing events in an estrous period.

Blood samples were taken once weekly starting on d 14 from all cows via coccygeal venipuncture into Monoject (Kendall Tyco Healthcare, Mansfield, MA) EDTA (K3) blood collection tubes. Samples were placed on ice until centrifuged at $2,500 \times g$ for $12 \mathrm{~min}$. Plasma was stored at $-60^{\circ} \mathrm{C}$ until radioimmunoassay (DSL-3400
Progesterone RIA kit, Diagnostic Systems Laboratories Inc., Webster, TX). Interassay variation was $9.2 \%$ and intraassay variation was $2.1 \%$. Plasma progesterone concentrations were used to classify cows as not having ovulated $(<1 \mathrm{ng} / \mathrm{mL})$ or as having ovulated $(\geq 1 \mathrm{ng} /$ $\mathrm{mL}$ ). In cows that showed estrus, days to first ovulation was determined from HeatWatch II data (onset of estrus) followed by evidence of high plasma progesterone $(\geq 1 \mathrm{ng} / \mathrm{mL}$ ) in a successive blood sample. In cows that did not show behavioral estrus associated with ovulation, the time of ovulation was estimated to be $4 \mathrm{~d}$ before high progesterone was detected (Shipka, 2000).

Transrectal ovarian ultrasonography $(7.5-\mathrm{MHz}$ linear probe, Sonovet 600, Alliance Medical, Bedford Hills, NY) was performed once weekly on all cows starting on d 14. The presence or absence of a corpus luteum was recorded and later compared with blood progesterone concentrations and radiotelemetric data.

Body condition scores were recorded for individual cows at enrollment and completion of the study to monitor BCS loss during the study. Scoring was conducted by 2 individuals using a 5 -point scale with 0.25 increments $(1=$ very thin and $5=$ obese; Edmonson et al., 1989) and the mean of the 2 scores was recorded.

Monthly milk weights were measured by a DHIA supervisor. Following DHIA records processing and laboratory analysis of milk samples, results (milk weights, protein percentage, and fat percentage) were transmitted electronically from the records processing center to the dairy computer, where all records were readily available.

Statistical analysis was performed using SAS (SAS Inst. Inc., Cary, NC). Cows were categorized into 2 groups based on BCS loss $(\geq 0.5$ BCS loss or $<0.5$ BCS loss) to investigate a possible effect of BCS loss on days to first ovulation. Data comparing loss of body condition to days to first ovulation were analyzed using a $t$-test. Cows were placed into 2 milk production groups, $<40 \mathrm{~kg} / \mathrm{d}$ and $\geq 40 \mathrm{~kg} / \mathrm{d}$, based on the average of the first 2 milk test weights, to investigate a possible effect of milk production on days to first ovulation. Data comparing milk test weights to days to first ovulation were also analyzed using a $t$-test. Data comparing parity to days to first ovulation were analyzed using a $t$-test.

First ovulation was associated with behavioral estrus in 5 cows and occurred at $28.2 \pm 10.8 \mathrm{~d}$ postpartum (mean $\pm \mathrm{SD}$; range 17 to $40 \mathrm{~d}$ ). The average duration of estrus was $6.0 \pm 4.9 \mathrm{~h}$ (range 3 to $12.2 \mathrm{~h}$ ), and average intensity was $18.4 \pm 8.8$ standing events (range 4 to 26). The average days to first ovulation in this study is similar to that of a previous study (29.1 \pm 3.0 d; Shipka, 2000). In a study using HeatWatch to 
investigate the timing of $\mathrm{AI}$ relative to the onset of estrus, a similar average duration of estrus was found $(7.1 \pm 5.4 \mathrm{~h})$; however, the average intensity of estrus was reported to be lower $(8.5 \pm 6.6$ standing events; Dransfield et al., 1998). A corpus luteum was visualized by ultrasonography in all 5 cows.

Based on progesterone concentrations $\geq 1 \mathrm{ng} / \mathrm{mL}$, 38 cows were determined to have had a first ovulation without associated estrous behavior (silent ovulation). This appears to be a much greater percentage (38/43; $88.4 \%$ ) of silent ovulations compared with a previous report (42\%; Shipka, 2000). However, Shipka (2000) classified cows as being in estrus if there was evidence of a single standing event, versus the criterion of 3 standing events in $4 \mathrm{~h}$ used in the present study. This may account for the apparent difference in percentage of silent ovulations reported between the studies. In cows that did not display estrous behavior, the first postpartum ovulation was estimated to occur at $25.1 \pm$ $10.4 \mathrm{~d}$ (range 10 to $49 \mathrm{~d}$ ). A CL was visualized by ultrasonography in 35 of 38 cows with a silent ovulation. Of the 38 cows, 22 showed no estrus activity during the study and 16 cows went on to display behavioral estrus associated with a second ovulation.

Two of the 5 cows that showed behavioral estrus associated with first ovulation and 16 of the cows that had a silent ovulation displayed estrus activity associated with a second ovulation. For these 18 cows, average duration of estrus was $5.5 \pm 4.2 \mathrm{~h}$ (range 1.7 to $18.9 \mathrm{~h}$ ) and average intensity of estrus was $13.4 \pm 10.4$ standing events (range 3 to 44). Four additional cows showed evidence of a second ovulation not associated with estrus before the end of the study period. Together, these 22 cows had an average interval from calving to second ovulation of $34.9 \pm 6.6 \mathrm{~d}$ (range 23 to $47 \mathrm{~d}$ ). For cows that exhibited first and second ovulations during the study period, the length of the estrous cycle was 16.7 $\pm 5.8 \mathrm{~d}$ (range 6 to $30 \mathrm{~d}$ ). This length of time appears similar to a previous study in which plasma progesterone concentrations were used to determine the length of the first estrous cycle $(14.9 \pm 1.4 \mathrm{~d}$; Webb et al., 1980).

Six animals $(8.5 \%)$ did not show evidence of ovulation based on blood progesterone concentrations and did not show evidence of estrus based on HeatWatch II data. The incidence of anovulatory anestrus on this dairy appeared to be lower than previously reported for cows at a similar stage of lactation (20 to 40\%; Moreira et al., 2001; Cerri et al., 2004; El-Zarkouny et al., 2004). The one crossbred cow in this study was part of the anovulatory group. An additional cow showed evidence of estrus the day before removal from the study (d 48). Data from this cow were not included in the results because ovulation could not be verified with a plasma progesterone sample.

Excessive loss of body condition after parturition is associated with increased days to first ovulation (Smith et al., 1983; Butler and Smith, 1989). Consequently, cows with evidence of a first ovulation and a complete BCS data set $(\mathrm{n}=40)$ were categorized into 2 groups based on BCS loss ( $\geq 0.5$ BCS loss or $<0.5$ BCS loss) to investigate a possible effect of BCS loss on days to first ovulation. Loss of body condition did not affect the interval to estimated first ovulation without estrus or first ovulation with estrus $(P=0.9)$.

To investigate the effect of milk production on days to first ovulation, cows with evidence of first ovulation with or without behavioral estrus and complete milk test weight data $(\mathrm{n}=41)$ were placed into 2 milk production groups, $<40 \mathrm{~kg} / \mathrm{d}(\mathrm{n}=20$; average milk test weight of $33.2 \pm 4.1 \mathrm{~kg} /$ cow $)$ and $\geq 40 \mathrm{~kg} / \mathrm{d}(\mathrm{n}=21$; average milk test weight of $48.9 \pm 5.2 \mathrm{~kg} / \mathrm{cow}$ ), based on the average of the first 2 milk test weights. Level of milk production did not affect the interval to estimated first ovulation without estrus or first ovulation associated with estrus $(P=0.7)$.

An effect of parity has been associated with reproductive performance in early postpartum dairy cows (Wenz et al., 2011; Dubuc et al., 2012). Therefore, cows were separated into 2 groups, primiparous $(\mathrm{n}=16)$ and multiparous $(\mathrm{n}=27)$, to investigate a possible effect of parity on days to first ovulation. No significant difference was found between these groups and days to first ovulation $(P=0.6)$.

Progesterone, ultrasound, and radiotelemetric data provide evidence that first ovulation postpartum occurs within approximately $28 \mathrm{~d}$ after calving. However, the majority of first ovulations $(38 / 43 ; 88.4 \%)$ were not associated with behavioral estrus. Taken together with the short average duration of estrus $(6.0 \pm 4.9 \mathrm{~h})$ associated with first ovulation, it is evident that detection of first behavioral estrus postpartum may be challenging. Consequently, dairy herds currently using an estrous detection-based management strategy should consider the addition of a presynchronization program to facilitate identification of cycling animals (likely at behavioral estrus associated with second ovulation) and to program or anticipate animals for AI after the end of the voluntary waiting period.

\section{ACKNOWLEDGMENTS}

This research was supported in part by the Idaho Agricultural Experiment Station and Select Sires Inc. (Plain City, OH). The authors thank Cow Chips LLC 
(Manalapan, NJ) for donation of the HeatWatch II system and the staff at Roorda Dairy (Caldwell, ID).

\section{REFERENCES}

Brusveen, D. J., A. P. Cunha, C. D. Silva, P. M. Cunha, R. A. Sterry, E. P. B. Silva, J. N. Guenther, and M. C. Wiltbank. 2008. Altering the time of the second gonadotropin-releasing hormone injection and artificial insemination (AI) during Ovsynch affects pregnancies per AI in lactating dairy cows. J. Dairy Sci. 91:1044-1052.

Butler, W. R., and R. D. Smith. 1989. Interrelationships between energy balance and postpartum reproductive function in dairy cattle. J. Dairy Sci. 72:767-783.

Casida, L. E. 1961. Present status of the repeat-breeder cow problem. J. Dairy Sci. 44:2323-2329.

Cerri, R. L. A., J. E. P. Santos, S. O. Juchem, K. N. Galvão, and R. C. Chebel. 2004. Timed artificial insemination with estradiol cypionate or insemination at estrus in high-producing dairy cows. J. Dairy Sci. 87:3704-3715.

Dransfield, M. B. G., R. L. Nebel, R. E. Pearson, and L. D. Warnick. 1998. Timing of insemination for dairy cows identified in estrus by radiotelemetric estrus detection system. J. Dairy Sci. 81:1874-1882.

Dubuc, J., T. F. Duffield, K. E. Leslie, J. S. Walton, and S. J. LeBlanc. 2012. Risk factors and effects of postpartum anovulation in dairy cows. J. Dairy Sci. 95:1845-1854.

Edmonson, A. J., I. J. Lean, L. D. Weaver, T. Farver, and G. Webster. 1989. A body condition scoring chart for Holstein dairy cows. J. Dairy Sci. 72:68-78.

El-Zarkouny, S. Z., J. A. Cartmill, B. A. Hensley, and J. S. Stevenson. 2004. Pregnancy in dairy cows after synchronized ovulation regimens with or without presynchronization and progesterone. J. Dairy Sci. 87:1024-1037.

Lucy, M. C. 2001. Reproductive loss in high-producing dairy cattle: Where will it end? J. Dairy Sci. 84:1277-1293.
Moeller, L. M., N. A. Michael, J. C. Dalton, and G. C. Lamb. 2010 Evaluating reproductive outcomes in United States Holstein dairies. J. Dairy Sci. 93(E-Suppl. 1):408. (Abstr.)

Moreira, F., C. Orlandi, C. A. Risco, R. Mattos, F. Lopes, and W. W. Thatcher. 2001. Effects of presynchronization and bovine somatotropin on pregnancy rates to timed artificial insemination protocol in lactating dairy cows. J. Dairy Sci. 84:1646-1659.

NRC. 2001. Nutrient Requirements of Dairy Cattle. 7th rev. ed. Natl. Acad. Sci., Washington, DC.

Pursley, J. R., M. R. Kosorok, and M. C. Wiltbank. 1997a. Reproductive management of lactating dairy cows using synchronization of ovulation. J. Dairy Sci. 80:301-306.

Pursley, J. R., R. W. Silcox, and M. C. Wiltbank. 1998. Effect of time of artificial insemination on pregnancy rates, calving rates, pregnancy loss, and gender ratio after synchronization of ovulation in lactating dairy cows. J. Dairy Sci. 81:2139-2144.

Pursley, J. R., M. C. Wiltbank, J. S. Stevenson, J. S. Ottobre, H. A. Garverick, and L. L. Anderson. 1997b. Pregnancy rates per artificial insemination for cows and heifers inseminated at a synchronized ovulation or synchronized estrus. J. Dairy Sci. 80:295-300.

Shipka, M. P. 2000. A note on silent ovulation identified by using radiotelemetry for estrous detection. Appl. Anim. Behav. Sci. $66: 153-159$

Smith, R. D., B. L. Perkins, C. J. Sniffen, and E. G. Pearson. 1983. Body condition and fatty liver in dairy cattle - Is there a relationship with reproductive performance? Pages 20-25 in Proc. Cornell Nutrition Conference. Cornell Univ., Ithaca, NY.

Washburn, S. P., W. J. Silvia, C. H. Brown, B. T. McDaniel, and A. J. McAllister. 2002. Trends in reproductive performance in southeastern Holstein and Jersey DHI herds. J. Dairy Sci. 85:244-251.

Webb, R., G. E. Lamming, N. B. Haynes, and G. R. Foxcroft. 1980 Plasma progesterone and gonadotrophin concentrations and ovarian activity in post-partum dairy cows. J. Reprod. Fertil. 59:133143.

Wenz, J. R., D. A. Moore, and R. Kasimanickam. 2011. Factors associated with the rectal temperature of Holstein dairy cows during the first 10 days in milk. J. Dairy Sci. 94:1864-1872. 